\title{
CONFLICTS OF RELIGIOUS EDUCATION IN A SECULAR STATE: A STUDY ON TURKEY'S IMAM-HATIP SCHOOL
}

\author{
Mohd Roslan Mohd Nor \\ University of Malaya, Kuala Lumpur, Malaysia \\ mroslan@um.edu.my \\ Muhammad Khalis Ibrahim \\ University of Malaya, Kuala Lumpur, Malaysia. \\ khalismuhammad92@yahoo.com
}

\begin{abstract}
Although the secularization process has been carried out tremendously in modern Turkey since the establishment of the republic, the role of religion (i.e. Islam) was not fully denied. This became more apparent especially in the area of education. In this regard, the Kemalist regime has established the Imam-Hatip School since the formation of modern Turkey. However, throughout its development, the schools have experienced various challenges and sanctions. Hence, this paper aims to discuss the conflicts faced by the Imam-Hatip School as a religious educational institution in Turkey and attempts that have been made to overcome the conflicts. Thispaper relies on the textual study by analyzing related documents, reports, and other previous studies. In general, the conflicts that struck the Imam-Hatip School were due to a narrative where its existence was contrary to the principle of secularism.
\end{abstract}


As a result, the schools were undermined by authorities where graduates from the schools were marginalized from pursuing their study in universities, and the schools were closed as an effect from the structuration of the schooling system. The conflicts have led some attempts to revive the status of the school as a religious educational institution. Although the attempts have led to positive implications, they also contributed to the polarization among people.

Keywords: Religious education, Imam-Hatip School, Turkey, conflicts, secular state.

\section{A. Introduction}

The establishment of modern Turkey has led the implementation of reformation and modernization processes. In implementing the reformation agenda, Mustafa Kemal Atatürk (1923-1938) has focused on the secularization process to modernize both the state and the Turkish society. Atatürk's secular approach was radical and assertive in nature, where it did not only marginalize political affairs from religion but also tended to separate public affairs from religion as a whole (Çelebi, 2011). This attempt portrays Kemalist vision to eradicate the role of Islam that has shaped the identity of the Turkish nation for a long time (Ibrahim \& Mohd Nor, 2018).

Since education is an important medium for social engineering, Atatürk has focused specifically on education in his attempt to secularize Turkish people. The Turkish parliament has approved unification of education system through the Law of Unification of Education (TevhidiTedrisatKanunu) on $3^{\text {rd }}$ March 1924 by making secular-based 
education as the fundamental framework for the education system. The unification of education system made religious education to be marginalized and no longer functioning and caused its elimination under the new law (Aşlamacı \& Kaymakcan, 2017). At the same time, the educational syllabus was framed by undermining divinity elements and applying only on rational and scientific-based methodologies.

Despite the secularization process has been carried out tremendously, the role of Islam as an influential force in Turkey was not fully denied. However, the function of religion has been limited only to a private matter, while the religious interpretation as a whole was placed under state monitoring. In this regard, the Kemalist regime has established the ImamHatip School since the formation of modern Turkey. ImamHatip School is a religious vocational school that serves as an educational institution to train future prayer leaders (imām), sermon readers (khațīb), and religious officials. Throughout its development, the Imam-Hatip School experienced various challenges and sanctions, whether directly or indirectly. Hence, this paper aims to discuss the conflicts faced by the Imam-Hatip School as a religious educational institution in Turkey. This paper outlines two key objectives, namely, to discuss the background oftheImam-Hatip School as a religious educational institution in Turkey, and to examine the conflicts faced by the school throughout its development.

Although several studies focus on studying the ImamHatip School [by naming some examples, e.g. (Aşlamacı \& Kaymakcan, 2017; Alasania \& Gelovani, 2011; Coşkun \& Şentürk, 2012; Junaedi, 2016; Çakmak, 2009; Öcal, 2007)], most of them mainly focus on historical and conflictual 
dimensions and not paying much attention to attempts that have been made to overcome conflicts and problems related to the school. The present paper, on the other hand, is unique due to its contribution to literature twofold. First, the present paper covers a wide area of discussion related to Imam-Hatip School starting from its historical background, development, conflicts, and attempts that have been made to overcome the conflicts of the school as one of the main religious educational institutions in Turkey. Second, this paper not only discusses attempts that have been made to overcome the conflicts of Imam-Hatip School but also tries to explain the implications of the attempts. This paper provides historical and narrative explanations for the development of the Imam-Hatip School up to its current development.

Structurally, this paper is organized into several sections. It first discusses the basis and historical background of the establishment of Imam-Hatip School as well as its curriculum syllabus. Next, this paper examines the conflicts faced by the school in the context of its operation in a contemporary secular Turkey. Then, it discusses several attempts that have been made to overcome those conflicts, and followed by implications of the attempts.

\section{B. The Basis and Historical Background of the Establishment of Imam-Hatip School}

Based on the idea of reforming the education system as a catalyst for secularization and modernization processes (Çakmak, 2009; Coşkun \& Şentürk, 2012), the Law of Unification of Education was introduced as early as the establishment of modern Turkey. The law has restructured 
the existing educational system where public schools, private schools, religious schools (medrese) and ethnical-based schools were placed under the Ministry of National Education (Öcal, 2007). In other words, the unification of education system has eliminated the categorization of schools. This made religious schools like medrese to lose their function and led them to be closed due to the curriculum standardization in all schools (Çakmak, 2009). In order to replace the role of medrese and to meet the need for preparatory servants in religious sectors such as imām, khațīb, and religious officials, Imam-Hatip School was established as a religious vocational school.

Basically, the legal basis of the establishment of ImamHatip School has been stated in Article 4 of the Law of Unification of Education (Öcal, 2007). Article 32 of the Basic Law of National Education further details the objective and scope of the Imam-Hatip School as follows:

\begin{abstract}
An IPS [Imam-Hatip School] is a teaching institution that has been opened by the Ministry of National Education which instructs its students in both religious services, such as imam, preacher, and teacher of Qur'anic courses, and which prepares them for higher education. (Öcal, 2007)
\end{abstract}

In the early phase of its establishment (1924-1929), 29 of Imam-Hatip School were established by taking over existing medreses (Aşlamacı \& Kaymakcan, 2017). During the first year of its establishment, 300 teachers were assigned to teach 2,258 students. However, both the number of students and teachers has dropped to 278 and 10, respectively, during the 1926-1927 school session. This happened because the 
government at that time shown less interest in the school, which then triggered perceptions among people that the school did not promise a good future prospect compared to public school. As the number of students continued to drop, Imam-Hatip School then was closed in 1929 (Junaedi, 2016).

However, the uncertainty of Imam-Hatip School's status ended with a shift in Turkey's political system from a single-party system to a multi-party system. In this regard, the implementation of the multi-party system began in 1946 has further emphasized the discourse of democracy, which then triggered a debate on the status of religious education in Turkey, including the Imam-Hatip School (Ibrahim \& Mohd Nor, 2018). The winning of the Democratic Party in the 1950 general election allowed the school to reopen after has been closed for two decades. On October 1951, the Imam-Hatip School'enrolment was offered for 1951-1952 school session in major cities such as Ankara, Adana, Istanbul, Isparta, Konya, and Kayseri. In fact, the Imam-Hatip School was also opened for both secondary and high schools, contrary to the previous era where the school just focused on the high school level. The increasing number of schools also affected the number of students from year to year (Alasania \& Gelovani, 2011).

Despite several political interventions through military coups in 1960, 1971, and 1980, the Imam-Hatip School continued to grow because of the high demands from parents who wanted their children to gain religious education while at the same time were not left behind to gain formal academic. However, the military coup in 1997 has affected the development of Imam-Hatip School due to the introduction of the new schooling system. The structuration 
of schooling system made the school to be closed during the next school session until it reopened in 2012 as a result of the implementation of the new schooling system.

In discussing the background of Imam-Hatip School, it is important to look at its curriculum as well. Generally, the Imam-Hatip School is a continuation of the medrese system which has been existed before the republican era (Aşlamacı \& Kaymakcan, 2017). Hence, the syllabus of its religious curriculum is not much different when compared to the medrese's curriculum. However, Imam-Hatip's curriculum has been updated by harmonizing between traditional and modern-style educations.

The curriculum syllabus of Imam-Hatip School consists of two main components, namely religious and academic courses. This means that the Imam-Hatip School's syllabus combines both religious and non-religious education. Religious courses consist of Theology, Qur'an, Islamic Scholasticism ('Ilm al-Kalām), Qur'anic Exegesis (Tafsīr), Prophetic Traditions (Hadīth), Islamic Creed ('Aqìdah), Islamic Jurisprudence (Fiqh), Life of the Prophet (Sïrah), History of Religions, Arabic Language, and Preaching and Vocational Training. On the other hand, academic courses comprise of Turkish Language and Literature, Mathematics, Biology, Physics, Chemistry, History, Geography, Psychology, Sociology, History of Islamic Arts, English Language, National Defense, History of Principles and Reforms of Kemalism, and Physical Education (Çakmak, 2009).

Courses taught at the Imam-Hatip School can be examined based on several aspects. First, it can be seen that the schools' syllabus promotes a sort of integration between 
religious and non-religious knowledge. Basically, this kind of educational syllabus is inherited from the Ottoman tradition, which emphasized the integration of mundane and spiritual education (Mat Sidek \& Mohd Talib, 2013; Haris, 2020). The curriculum structure is a significant aspect to determine in which direction the students of the school would be channeled (Çakmak, 2009). In this case, its integrated curriculum between religious and academic courses can be understood to create generations that understand the principles of religion and at the same time, mastering the secular-academic knowledge (Ibrahim \& Mohd Nor, 2018). Second, although Imam-Hatip is a religious school, there are more academic courses compared to religious courses that have been taught. As stated above, there are 14 subjects under the academic courses compared to 11 subjects under the religious courses. This dualism educational system illustrates the uniqueness of Imam-Hatip School compared to previous religious educational institutions that focus more on teaching religious subjects. Third, it is found that the religious subjects taught at the Imam-Hatip School consist of fundamental disciplines that framing the core understandings of Islam. At the same time, students are also exposed to several core academic courses such as language, culture, and nationhood which have been taught in other schools as well (Öcal, 2007). Indirectly, this implies that the Imam-Hatip Schoolwas created to educate students to understand well in both religion and Turkish nationalism, which symbolize their core identity. 


\section{The Existence of Imam-Hatip School Challenging the Principles of Turkish Secularism}

Generally, the establishment of Imam-Hatip School was welcomed by the Turkish community (Öcal, 2007). However, its existence remains unpopular by some people, thus inviting some conflicts to the school. In Turkey, there is a small elite group who strongly adheres to the principle of secularism and dominate economic and political spectra. According to them, religious institutions such as the Imam-Hatip School were considered as a threat to the principle of secularism (Gür, 2016). The presence of Imam-Hatip School was seen as promoting religious education with the inspiration from the Sunni tradition and neglecting secular-paradigm education (Christie-Miller, 2014). Thus, the schools were perceived to eradicate the principle of secularism that is understood as the identity of the Turkish state, through the application of religious education.

In addition, the Imam-Hatip School also has been seen acting as "factories" in recruiting "Islamist cadres." As the students of Imam-Hatip School are also being taught with academic courses along with religious courses, theoretically, they are able to position themselves in various sectors, not only in a religious sector after graduation. For instance, Turkish President, RecepTayyipErdoğan (2014-present) himself was once a student from the Imam-Hatip School. According to some analysts, the schools have potential to become a platform for directing ideas and influences of Islamic fundamentalism, which in turn may giving birth to "Islamist generations," whether moderate or radical (Çakmak, 2009; 
Christie-Miller, 2014). However, contrary to this notion, some argue that the Imam-Hatip School as a moderate and ideal educational institution to be adopted by Muslim countries (Aşlamacı \& Kaymakcan, 2017).

\section{The Marginalization of Imam-Hatip School Graduates}

As the Imam-Hatip School has been perceived contrary to the principle of secularism, some attempts have been made to restrict its development. Following the 1997 military coup, the Turkish Higher Education Council (YüksekÖğretimKurulu-YÖK) imposed a law where the high schools' graduates who attend university admission examination are easier to pursue their studies in the same area as what they have taken during high school. In other words, it was difficult for the students of ImamHatip School who wish to pursue their studies other than religious area since they have to gain a higher score in their examination compared to students from the other schools as their weightage marks are relatively lower than those from the public schools. This made graduates from the Imam-Hatip School were more susceptible to the religious area only, especially to the faculty of theology, and difficult to pursue their studies in other area (Rabasa \& Larrabee, 2008).

If scrutinized, the law was discriminating the graduates of Imam-Hatip School since the curriculum of the schools not consist only religious subjects but also includes academic subjects (Öcal, 2007). Plus, a report issued by the US Bureau of Democracy, Human Rights, 
and Labor in 2006 stated that not all parents sent their children to the Imam-HatipSchool to serve in the religious sector. Some of them sent their children to ensure that their children receive both formal religious and academic education (Bureau of Democracy Human Rights and Labor, 2006). Therefore, the rights for the graduates of ImamHatip School to further their studies in any area according to their interests and results is relevant and appropriate as they also learn academic courses like students from other schools.

\section{Restructuring of Schooling System and the Closing of Imam-Hatip School}

Prior to 1997, the schooling system in Turkey was based on a concept of five years of compulsory education at a primary level. Then, parents were free to send their children for secondary level either to public or vocational schools, including the Imam-Hatip School. However, the schooling system has undergone change after 1997. Started from 1998, the schooling system adopted the " $5+3$ " compulsory education, i.e. five years of primary school (first to fifth grade) and three years of secondary school (sixth to eighth grade). In contrast to the previous system that gave freedom for parents to send their children to other type of schools after completing five years of primary school, the newly introduced system required students to complete their compulsory schooling session for eight years (Kloesel, 2014). As a result, students were obliged to spend their schooling period at public schools for eight years and were not allowed to enter other type of schools during that period. 
At first glance, the new schooling system introduced was only a change made to the compulsory education from five to eight years. However, the new system implicitly can be understood as an attempt to prevent students from entering the Imam-Hatip School as the new schooling system directly affected the school itself. As students were obliged to complete their eight-year school session at the regular public schools, the Imam-Hatip School became no longer relevant for the secondary level. The change has affected enrolment of the Imam-Hatip School until the next several years where the number has dropped dramatically after the system was introduced. Finally, the Imam-Hatip School for the secondary level (sixth to eighth grade) were closed down started from the 1999-2000 schooling session and only opened to students who has completed eight-year school session (Kaya, 2015). This development then affected the enrolment of the Imam-Hatip School at the high school level as well. Although continued to operate after the change of the schooling system, the number of students who entered the Imam-Hatip School for the high school level has experienced a drastic declination due to the lack of continuity from the Imam-Hatip School at the secondary level.

\section{Attempts to Overcome the Conflicts}

Following the law issued in 1997, the graduates of Imam-Hatip School faced difficulties in pursuing their studies at the university level. To enhance the competitiveness of the Imam-Hatip School's graduates, a parliamentary member from the ruling party; the Justice and Development Party (JDP) proposed in parliament on $4^{\text {th }}$ May 2004 so that the graduates 
of Imam-Hatipwere given flexibility for the university admission. At first, the proposal was agreed by the majority of the parliament members on $13^{\text {th }}$ May 2004. However, on $27^{\text {th }}$ May 2004, the then Turkish President; NecdetSezer (20002007) used his veto power to null the decision (Jenkins, 2007).

The failure of the early attempt was followed by the initiative made by the then National Education Minister; Hüseyin Çelik (2003-2009). He proposed an imposition in December 2005 to enable the graduates of Imam-Hatip School to enter the faculty other than religious faculty, where the students were required to enter public schools in their final year of high school by taking some basic courses. However, YÖK, which was still monopolized by secularists, has rejected the proposal because, for them, the proposal was contrary to the principle of secularism (Rabasa \& Larrabee, 2008; Köni \& Açıkgöz, 2013).

Although the early attempts did not succeed, the next attempt has brought result. Through the restructuring of university entry requirements made by YÖK, starting from the 2011 university academic session, the graduates of ImamHatip School have been allowed to continue their studies at any faculty according to their academic achievements and interests (Makovsky, 2015). Thus, the regulation where the graduates of Imam-Hatip School will only be channeled to the religious faculty was abolished starting from that session.

If scrutinized, attempts made to provide the opportunity for the graduates of Imam-Hatip School to pursue their interests at universities have faced two difficulties. The first attempt faced hostility from the then President, Necdet Sezer, who strongly adhered to the principle of secularism. He used 
his veto power by rejecting the decision made by the majority of the parliamentary members. The second attempt faced a constraint from YÖK which at that time was monopolized by secularist bloc (Patton, 2007). On the other hand, the flexibility of the university admission requirement that came into force since 2011 has brought a result. This was due to the Turkish President who replaced Necdet Sezer, Abdullah Gül (20072014) from the JDP, was a pro-Islamist and conservative person that put no hostility towards the Imam-Hatip School. Plus, the restructuring of YÖK by placing moderate individuals or more precisely pro-JDP proxy(Akyol, 2014) also paved the way for the relaxation of admission to universities.

\section{E. Re-opening of Imam-Hatip School at the Secondary Level}

On $1^{\text {st }}$ February 2012, the then Turkish Prime Minister; Recep Tayyip Erdoğan (2003-2014) has announced in the JDP party conference on his intention to create pious generations. He asserted that:

Do you expect the conservative democrat AK Party [JDP] to raise atheist generations? This may be your business and objective but not ours. We will raise a generation that is conservative and democratic and embraces the values and historical principles of its nation (Hürriyet Daily News, 2012).

The announcement of the desire to create pious generations was an important episode for the context of the development of religious education in Turkey. On $20^{\text {th }}$ February 2012, JDP representative proposed in parliament to restructure the existing schooling system. The proposal 
was supported by the majority of the parliament members, which then was enacted on $30^{\text {th }}$ March 2012 as Law to Making Amendments on Primary Education Law. The law was officially gazetted on $11^{\text {th }}$ April 2012 which enabled it to immediately active (Gün \& Baskan, 2014). The new system was known as the " $4+4+4$ system" where the compulsory education consists of four years of primary school, four years of secondary school, and four years of high school. The change made the compulsory schooling period to be extended to 12 years compared to eight years under the previous system.

The new system introduced has affected the development of the Imam-Hatip School. Through the new system, parents were free to send their children either to regular public schools or to vocational schools such as the Imam-Hatip School for the secondary level. Thus, the $4+4$ +4 schooling system introduced has restored the position of Imam-Hatip School at the secondary level. As a result, the school has re-opened in the 2012-2013 sessions and since then has experienced an increase in number (see Table 1).

Table1. The number of Imam-HatipSchooloperating in the secondary level (from 1995-1996 sessions until 2016-2017 session)

\begin{tabular}{lcc}
\hline School session & Num. of schools & Num. of students \\
\hline $1995-1996$ & 479 & 306,684 \\
$1996-1997$ & 601 & 318,775 \\
$1997-1998$ & 604 & 218,631 \\
$1998-1999$ & 612 & 0 \\
$1999-2000^{*}$ & 0 & 0 \\
$2012-2013$ & 1,099 & 94,467 \\
$2013-2014$ & 1,361 & 240,015 \\
$2014-2015$ & 1,597 & 385,830 \\
$2015-2016$ & 1,961 & 524,295 \\
$2016-2017$ & 2,671 & 651,954 \\
\hline
\end{tabular}


*starting from the 1999-2000 session until the 2011-2012 session, the Imam-Hatip School in the secondary level have been closed following the implementation of the $5+3$ schooling system. The schools have been reopened starting from the 2012-2013 session after the restructuring of the schooling system.

Sources: (Millî Eğitim Bakanliği, n.d.; Makovsky, 2015; Ibrahim \& Mohd Nor, 2018)

Based on Table 1 above, the reopening of the ImamHatip School at the secondary level during the 2012-2013 school sessions and followed by the increase of its number consistently until the 2016-2017 school session was driven by several factors. First, the shift in schooling system from eight years to 12 years enabled the Imam-Hatip School to become as one of the choices for secondary schools. Second, the new examination system introduced gave an advantage to the schools, where educational law stipulates that all students are required to take examination to enter secondary schools unless those who wish to enter the Imam-Hatip School. Students who did not pass the examination had no other choice but to continue their studies at the Imam-Hatip School (Rahman, Nawi, \& Ahmad, 2017). Third, the flexibility given to the graduates of Imam-Hatip School to enter any faculty other than religious-based faculties puts them equally with the rest of graduates from the other schools. And fourth, some of the public schools were converted to Imam-Hatip School to meet the increasing demands and needs.

\section{F. Implications of the Attempts in Overcoming Conflicts}

The attempts to overcome the conflicts that struck the Imam-Hatip School have given some implications on both the Imam-Hatip students as well as the Turkish people in 
general. Generally, the initiative to enable the graduates of Imam-Hatip School to further their studies in various areas at universities has increased the competitiveness of the students as equivalent to the students from public high schools. This development provides benefits to the Imam-Hatip School students as they are not only able to study in the religious area, but also have the opportunity to continue their studies at the university level in any area as they wish. Opportunities to pursue studies in the various areas at universities allow them to explore areas of interest as a preparatory before entering an employment arena. This development is contrary to the previous era where the Imam-Hatip School graduates were only allowed to pursue studies at a religious faculty. Therefore, the career prospects for the Imam-Hatip School graduates after they graduate from universities have been widened and not limited to a religious area only.

In addition, the reopening of the Imam-Hatip School at the secondary level through the restructuring of the schooling system serves more choice for students who have finished their primary school whether to enter public secondary schools or vocational schools like Imam-Hatip. In this regard, the ImamHatip School act as an alternative for students who want to learn religious courses formally and at the same time are able to study academic courses. The Imam-Hatip School not only serve as the platform totrain imām, khațīb, and religious officials, but they also contribute to producing students with high religious awareness (Junaedi, 2016). As a result of the integration between religious and academic courses, students from the Imam-Hatip School will always devout to the religious understanding regardless of their positions and 
roles in the future. Hence, the existence of the Imam-Hatip School is a significant alternative to public schools.

At the same time, there is also a negative implication that results from the attempts made to overcome the conflicts of the Imam-Hatip School. Although Turkey was founded based on a secular framework, conservative people with a tendency towards religion comprise of a large population of the state (Hussein \& Ayten, 2017). As a party with a pragmatic approach, the JDP as the government always ensures that the popular demand of the people can be fulfilled through the implementation of its policies. In this regard, the attempts to empower the Imam-Hatip School have received good responses among some people, where it has been manifested through the commitment of some parents who chose to send their children to religious schools such as the Imam-Hatip rather than to the public schools(Şimşek, 2013). However, there were some of the Turkish people who opposed this development. For instance, the initiative of transforming public schools into the Imam-Hatip School has received opposition from some parents who want a fully secular education for their children. For them, the agenda of creating pious generations has become a catalyst for the empowerment of religious education that has caused tension and polarization amongpeople (Yeginsu, 2014).

To date, the issue of polarization of people is still happening in Turkey. This problem did not occur due to the attempts of the JDP government to overcome conflicts of the Imam-Hatip School per se. Whereas, it is a reflection of Turkey's sociopolitical development, which shows that there is a fracture of the people's tendency towards the party they 
are supporting. The proportional representation system used in the Turkish elections allowed the JDP to form a single-party government as the other parties failed to secure a minimum of 10 percent vote to send their representatives to parliament. However, the JDP has only received about 35 to 49 percent votes since it first came to the polls. This means that the party did not receive support from a large majority of voters (Ibrahim, 2019).

As a pragmatic and populist pro-Islamist party, the JDP has been trying to balance its tendency towards pro-Islamic policies and the need to maintain its support. That is why in the issue of Imam-Hatip School, for example, the JDP adopted a moderate and soft approach by restructuring the schooling system and providing more space for the Imam-Hatip School to operate. Although these attempts were welcomed by about 50 percent of conservative and religious people who support the JDP, the party's attempts have been opposed by another 50 percent of people who do not support them, which mainly comprised of those who practice secular lifestyle. Polarization among people between those who tend to a conservative and religious way of life and those who tend to a secular lifestyle is a serious issue and continue to remain alongside the sociopolitical development in Turkey. Hence, it is of utmost importance for the JDP as a government to recognize and understand the complexity of its people by not marginalizing any segment of people regardless of ideology and political affiliation.

\section{G. Conclusion}

Basically, the conflicts that struck the Imam-Hatip School were due to a narrative where its existence was contrary to 
the principle of secularism. However, the authors view that this claim is somewhat irrelevant by taking into consideration the basis and historical background of its establishment. In fact, the establishment of the school was a result of the Law of Unification of Education which has been enacted since 1924, i.e. during the establishment of the modern Turkish state. Although Atatürk has carried out the secularization process, the Imam-Hatip School were left to keep operating during his reign until it had to be closed after six years of its operation due to the lack of interest among students. Hence, the claim where the schools are contrary to the principle of secularism is irrelevant based on the legal basis and history of its establishment.

The conflicts have invited some attempts to revive the status of the school as a religious educational institution. In this case, the Turkish government under the JDP has made some efforts until the graduates of Imam-HatipSchool were allowed to continue their study at universities and at the same time, allowing the school to re-open at the secondary level. Although the attempts have led to positive implications, they also contributed to the polarization among people. Here, the authors maintain that the JDP needs to look more closely at every voice from its people, either from the conservativeIslamic or secular groups, and not merely focusing on the interests of certain particular segments. Hence, the JDP's pragmatic approach should inspire the party to be more democratic by hearing every voice from various parties. 


\section{REFERENCES}

Akyol, M. (2014). Erdoğan's attack on private universities. Retrieved from Hürriyet Daily News: http://www. hurriyetdailynews.com/opinion/mustafa-akyol/ erdogans-attack-on-private-universities-68218.

Alasania, G., \& Gelovani, N. (2011). Islam and Religious Education in Turkey. Scientific Journal of International Black Sea University 5(2), 35-50.

Aşlamacı, I., \& Kaymakcan, R. (2017). A model for Islamic education from Turkey: The Imam-Hatip schools. British Journal of Religious Education 39(3), 279-292.

Bureau of Democracy Human Rights and Labor. (2006). Turkey: International Religious Freedom Report 2006. Retrieved from U.S. Department of State: https://www. state.gov/j/drl/rls/irf/2006/71413.html

Çakmak, D. (2009). Pro-Islamic Public Education in Turkey: The Imam-Hatıp Schools. Middle Eastern Studies 45(5), 825-846.

Çelebi, B. (2011). The Failure of Assertive Secularization Project in Turkey. Turkish Journal Politics 2(1), 89-98.

Christie-Miller, A. (2014). Erdogan Launches Sunni Islamist Revival in Turkish Schools. Retrieved from Newsweek: http: / / www.newsweek.com / 2014 / 12 / 26 / erdogan-launches-sunni-islamist-revival-turkishschools-292237.html.

Cornell, S. E. (2015). The Islamization of Turkey: Erdoğan's Education Reforms. Retrieved from Turkey Analyst: https://www.turkeyanalyst.org/publications/turkeyanalyst-articles/item/437-the-islamization-of-turkey- 
erdo\%C4\%9Fan\%E2\%80\%99s-education-reforms. html.

Coşkun, M. K., \& Şentürk, B. (2012). The Growth of Islamic Education in Turkey: The AKP's Policies toward ImamHatip Schools. In K. İnal, \& GülizAkkaymak, Neoliberal Transformation of Education in Turkey (pp. 165-177). New York: Palgrave Macmillan.

Gün, F., \& Baskan, G. A. (2014). New Education System in Turkey (4+4+4): A Critical Outlook. Procedia-Social and Behavioral Sciences 131, 229-235.

Gür, B. S. (2016). What Erdoğan Really wants for education in Turkey: Islamization or Pluralisation? . Retrieved from Al Jazeera Centre for Studies.

Haris, A. H. (2020). Sejarah Kerajaan Turki Uthmaniyyah dan Sumbangannya dalam Bidang Sosiopolitik Abad ke-14 hingga Abad ke-20. Journal of Al-Tamaddun 15(1), 85107.

Hürriyet Daily News. (2012). Debate on religion takes over politics in Ankara. Retrieved from http://www. hurriyetdailynews.com/debate-on-religion-takes-overpolitics-in-ankara-12814.

Hussein, A., \& Ayten, A. (2017). A New Era for Turkey the Attempted Coup of the 15 th of July. International Journal of West Asian Studies 9(1), 1-11.

Ibrahim, M. K. (2019). Peranan Adalet ve Kalkinma Partisi (AKP) pada Era Erdogan dalam Perkembangan Islam di Turki (2010-2017) (Unpublished master's dissertation). Academy of Islamic Studies, University of Malaya, Kuala Lumpur, Malaysia. 
Ibrahim, M. K., \& Mohd Nor, M. R. (2018). Cabaran Pendidikan Islam di Turki: Usaha AKP terhadap Pemerkasaan Sekolah Imam-Hatip. International Journal of West Asian Studies 10(1), 1-12.

Jenkins, G. (2007). Contituity and Change: Prospects for CivilMilitary Relations in Turkey. International Affairs 83(2), 339-355.

Junaedi, M. (2016). Imam Hatip School (Imam HatipLisesi): Islamic School in Contemporary Turkey. Analisa Journal of Social Science and Religion 1(1), 121-138.

Kaya, A. (2015). Islamisation of Turkey under the AKP Rule: Empowering Family, Faith and Charity. South European Society and Politics 20(1), 47-69.

Kloesel, L. (2014). Educational System of Turkey. Retrieved from NAFSA: http://www.nafsa.org/Professional_ Resources/Browse_by_Interest/International_ Students_and_Scholars/Network_Resources / International_Enrollment_Management/Educational_ System_of_Turkey/.

Köni, H., \& Açıkgöz, M. (2013). Politics of Religion in Turkey from National View to the Justice and Development Party. International Journal of Research in Social Sciences 3(2), 48-56.

Makovsky, A. (2015). Re-Educating Turkey AKP Efforts to Promote Religious Values in Turkish Schools. Washington: Center for American Progress.

Mat Sidek, R. S., \& Mohd Talib, N. (2013). Perkembangan Sains Tabi'i Islam Era Uthmaniyyah. Jurnal Al-Tamaddun 8(2), 37-47. 
Millî Eğitim Bakanliği. (n.d.). Millî Eğitim IstatiskleriÖrgün Eğitim [National Education Statistics - Formal Education]. Retrieved from http://sgb.meb.gov.tr/ www/resmi-istatistikler/icerik/64.

Öcal, M. (2007). From the Past to the Present: Imam and Preacher Schools in Turkey-An Ongoing Quarrel. Religious Education 102(2), 191-205.

Patton, M. J. (2007). AKP Reform Fatigue in Turkey: What has happened to the EU Process? Mediterranean Politics 12(3), 339-358.

Rabasa, A., \& Larrabee, F. S. (2008). The Rise of Political Islam in Turkey. California: RAND Corporation.

Rahman, A. A., Nawi, N. M., \& Ahmad, M. S. (2017). Erdogan Bukan Pejuang Islam? Kuala Lumpur: PTS Publications \& Distributors.

Şimşek, S. (2013). Conservative Democracy as a Cosmetic Image in Turkish Politics: The Semiology of AKP's Political Identity. Turkish Studies 14(3), 429-446.

Yeginsu, C. (2014). Turkey Promotes Religious Schools, Often Defying Parents. Retrieved from The New York Times: https://www.nytimes.com/2014/12/17/world/ europe/turkeys-religious-schools-rise-as-erdoganexerts-sway.html. 